\title{
COMPARISON OF DIFFERENT INSTRUMENTS FOR Evaluation OF COLOSTRUM QUALITY IN Dairy CatTle
}

\author{
Mergedus, A.; HARIH, L.; HOHLER, A.; JANZEKOVIC, M. \& BRUS, \\ M.
}

Abstract: The study's main objective was to evaluate the colostrum quality (immunoglobulin $G, \operatorname{Ig} G)$ at birth $(O h)$ and $3 h$ and $6 h$ after calving with different measurement devices foloving the comparison of the results among them. Colostrum samples $(n=63)$ were collected from 21 dairy caws. The colostrum quality was evaluated with a colostrometer and digital and optical refractometers. Digital and optical refractometers showed no significant $(P>0.05)$ diference in obdeind results, while colostrometers exhibited significantl $(P \leq 0.05)$ lower concentrations of IgG. Differences were detected in all three considered times. The colostrometer proved to be less accurate. The optical refractometer proved to be the most useful for on-farm assessment because the results were comparable to the digital and it was affordable.

Key words: colostrum quality, immunoglobulin $G$, colostrometer, optical and digital Brix refractometer
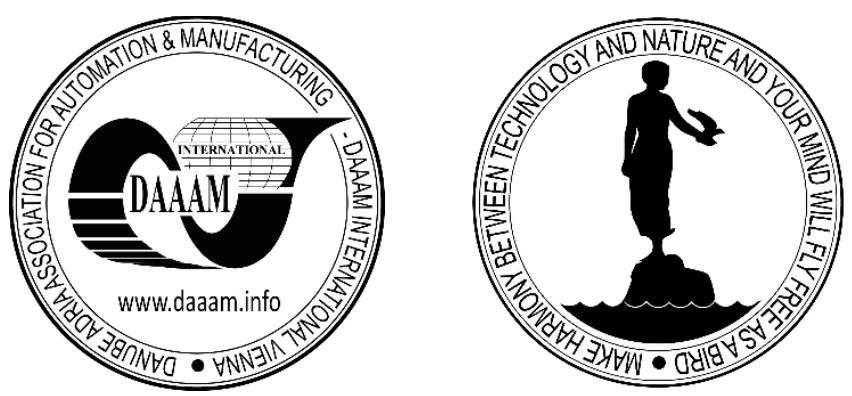

Authors' data: Dr. Sc. Mergedus, A[ndrej]*; Harih, L[eon]*; M. Sc. Hohler A[nton]**; Assis. Prof. Dr. Sc. Janzekovic M[arjan]* \& Dr. Sc. Brus, M[aksimiljan]*. * University of Maribor, Faculty of Agriculture and Life Sciences, Pivola 11, 2311 Hoce, Slovenia, ** KGZS Ptuj, Ormoška cesta 28, 2250 Ptuj, Slovenia, andrej.mergedus@um.si, harih.leon@gmail.com, anton.hohler@kgz-ptuj.si, marjan.janzekovic@um.si, maksimiljan.brus@um.si.

This Publication has to be referred as: Mergedus, A[ndrej]; Harih, G[regor]; Hohler, A[nton]; Janzekovic, I[gnac] \& Brus, M[aksimiljan] (2020). Comparison of Different Instruments for Evaluation of Colostrum Quality in Dairy Cattle, Chapter 07 in DAAAM International Scientific Book 2020, pp.091-098, B. Katalinic (Ed.), Published by DAAAM International, ISBN 978-3-902734-27-3, ISSN 1726-9687, Vienna, Austria

DOI: 10.2507/daaam.scibook.2020.07 
Mergedus, A.; Harih, G.; Hohler, A.; Janzekovic, I. \& Brus, M.: Comparison of Dif...

\section{Introduction}

Colostrum is the first milk produced by the mammary glands in late pregnancy and parturition and is an essential source of immune protection and nutrition for the newborn. In cattle, the immunoglobulins (antibodies) cannot cross the placental structure. Calves are born agammaglobulinemic with no measurable circulating immunoglobulins (Morrill et al., 2015). This means that calves are born with minimal immunological defence against environmental pathogens. Calves must ensure their passive immunity by consuming colostrum as soon as possible after their birth. Right time and sufficient supply of calves with quality colostrum is essential for the survival, could reduce mortality, strengthen immunity and increase livability of newborn (Janzekovic et al., 2014; Yaylak et al., 2018).

The composition of colostrum is different from the composition of milk and is adapted to the needs of newborn calves. The change in composition is already visible to the eye, as the colostrum is thicker than milk and slightly yellowish in colour. Significant variability in the composition and concentration of colostrum components has been reported. Factors affecting its composition are breed, parity, pre-partum nutrition, length of the dry period of cows and time postpartum, age of cows, time of year, frequency of milking, milking procedures and udder health (Puppel et al. 2019).

Colostrum is rich in nutrients and non-nutrient biologically active components, including carbohydrates, proteins, growth factors, enzymes, enzyme inhibitors, nucleotides and nucleosides, cytokines, fats, minerals and vitamins. Colostrum contains less lactose but significantly more dry matter than milk, the largest share of which belongs to protein. There are also significantly more minerals and vitamins in colostrum (McGrath et al., 2016; McGee \& Earley, 2019). The proportion of proteins with specific functions - immunoglobulins - is exceptionally high. Three classes of immunoglobulins have been identified in cows' colostrum and milk: $\operatorname{IgG}$, IgA, and IgM. The primary immunoglobulin is IgG. The IgG immunoglobulins can be divided into two subclasses: IgG1 and IgG2 (Butler, 1969).

Colostrum is secreted from the udder in the first three to five days after birth (Conte \& Scarantino 2013). Quality of colostrum rapidly reduces over the period after parturition. Similarly, its biological and nurturing values decrease over time. Except for the case of lactose, the levels of other compounds decrease during the first 3 days of lactation. Even more, colostrum's composition changes with each hour. Time constitutes represent a critical element for feeding calves with colostrum. It is crucial to provide colostrum immediately after birth (0.5-1 h) (Puppel et al., 2019). Sacerdote et al. (2013) measured the highest concentrations of IgG in samples obtained in the first $4 \mathrm{~h}$ after delivery, and its levels decreased after $6 \mathrm{~h}$. IgG levels vary widely from cow to cow and range from less than 20 to over $100 \mathrm{mg} / \mathrm{mL}$ Current recommendations are to feed 3 to $4 \mathrm{~L}$ of high-quality ( $>50 \mathrm{~g}$ of $\mathrm{IgG} / \mathrm{L}$ and $<100,000$ colony-forming unit (CFU) of total bacteria/ml and $<10,000 \mathrm{CFU}$ of coliform bacteria/ml) colostrum to dairy calves within the first $6 \mathrm{~h}$ after birth (Alley et al., 2012). 
The quality of colostrum can be evaluated by measuring the colostral $\mathrm{IgG}$ concentration. The estimation can be performed directly or indirectly. Direct determination of colostrum quality is by laboratory methods such as radial immunodiffusion (RID) and turbidimetric immunoassay (Alley et al., 2012).

For both methods in laboratory is in common to be time-consuming, high in cost, and lack automation (Elsohaby et al., 2017). Indirect assessments of the colostrum quality are done by using on-farm small apparatus or devices such as colostrometer, and Brix optical or digital refractometer. Colostrometer, measure the specific gravity using a calibrated scale in milligrams per milliliter $(\mathrm{mg} / \mathrm{mL})$ of immunoglobulins ( $\mathrm{Ig}$ ), converting specific gravity to Ig concentrations. Refractometer is designed to measure the refractive index of liquids using a Brix score (Bartens et al., 2016).

The objectives (aims) of our study were to evaluate the accuracy of three devices: colostrometer and Brix optical and digital refractometer in order to assess the quality of colostrum and compare results among them, and their suitability to use them on farms.

\section{Materials and methods}

\subsection{Colostrum sample collection and measuring devices}

As a part of the study, colostrum samples $(n=63)$ were collected from 21 dairy cows that calved during the period from 6 May to 30 September 2019. We evaluated the quality of colostrum immediately after calving, and 3 and 6 hours postpartum. All three evaluations were performed with a colostrometer, an optical refractometer and a digital refractometer.

For evaluation with a colostrometer, approximately $0.5 \mathrm{~L}$ of colostrum was milked from the udder. A colostrometer with a rubber vacuum pump was used, to pump the colostrum into a cylinder (Fig. 1). The measuring scale in colostrometer is placed in a cylinder and can float freely. The whole device was immersed in the colostrum and the rubber pump was slowly released.

When $1 \mathrm{dl}$ of colostrum was pumped into the cylinder, the additional 5 minutes were needed for bubbles on the surface to disappear. Then the values on the measuring scale were noted. Scale measured range was from $25 \mathrm{~g} / \mathrm{L}$ to $125 \mathrm{~g} / \mathrm{L}$. The colostrometer was carefully cleaned after each use. 
Mergedus, A.; Harih, G.; Hohler, A.; Janzekovic, I. \& Brus, M.: Comparison of Dif...

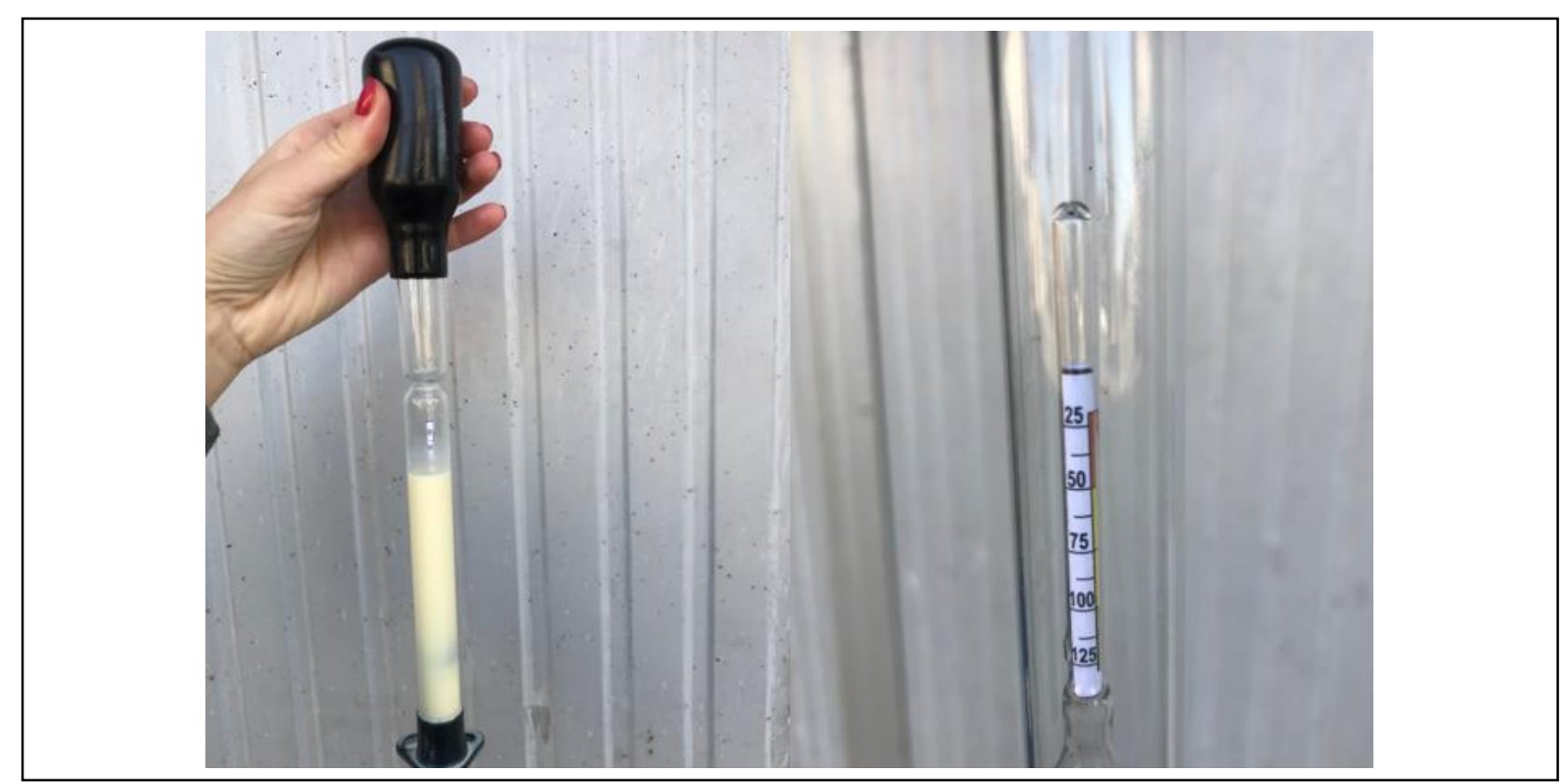

Fig. 1. Colostrometer and scale of the colostrometer (Harih, 2019).

For evaluations based on optical and digital refractometers, colostrum samples were taken from front left udder each time. Before collecting the samples, we cleaned the udder and turned on the digital refractometer (Fig. 2), to measure the ambient temperature. After first few jets of colostrum that we ignored then next few drops of milk (colostrum) we milked to the window on a digital refractometer to take the assessment of the sample. After the assessment, we cleaned the window with a disinfectant tissue. The same procedure was repeated for measurements by optical refractometer (Fig. 3). A few drops were milked onto a prism on an optical refractometer. After the temperature of the colostrum was adjusted to the ambient temperature, optical refractometer was turned towards the light source and the values were noted. The Brix value was read at the line between the light and dark areas that appeared on the scale.

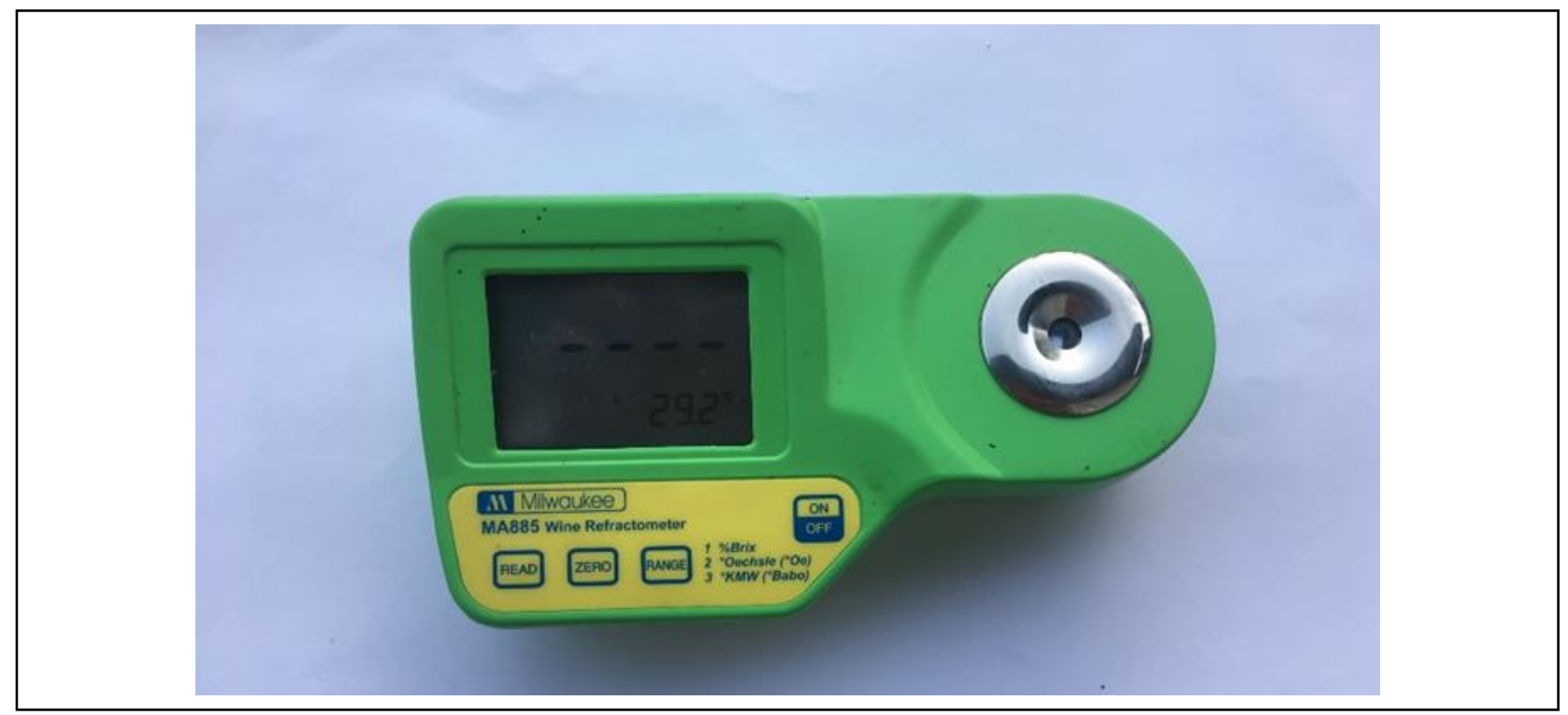

Fig. 2. Digital refractometer (Harih, 2019). 


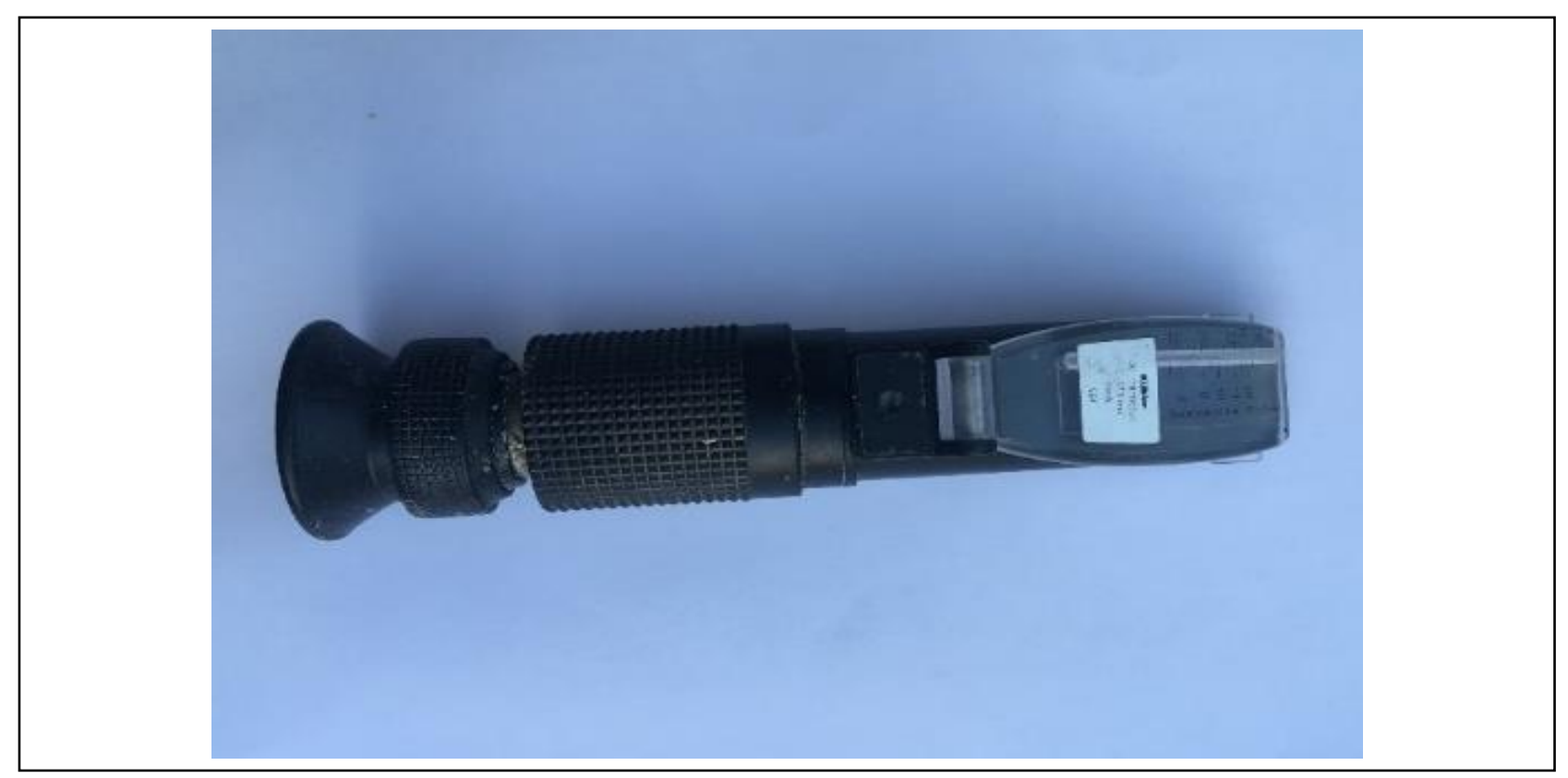

Fig. 3. Optical refractometer (Harih, 2019).

The results of colostrometer were obtained in $\mathrm{g} / \mathrm{L}$, while measurements from both refractometers were noted in percentages $(\%)$. The results of both refractometer measurements were then converted to $\mathrm{IgG}$ concentration $(\mathrm{g} / \mathrm{L})$ based on the formula y $=-61.896+5.666 \times$ Brix (\%), according to Quigley et al. (2013). For interpretation of the results of low or high quality of colostrum, we used data from Bartier et al. (2015) in Tab. 1.

\begin{tabular}{|l|l|l|}
\hline BRIX (\%) & IgG concentration $(\mathrm{g} / \mathrm{L})$ & Quality of colostrum \\
\hline$>30$ & $>80$ & Very good \\
\hline $23-30$ & $50-80$ & Good \\
\hline $15-22$ & $28-50$ & Middle \\
\hline$<15$ & $<27$ & Poor \\
\hline
\end{tabular}

Tab.1. Interpretation of the obtained results (Bartier et al. 2015).

\subsection{Statistical analysis}

Statistical analysis was performed with the statistical software package SPSS 25.0. GLM univariate analysis was used to analyze the data and the Tukey test was used to compare the differences between the tested groups. The observed statistical differences at $\mathrm{P} \leq 0.05$, were denoted by $\mathrm{a}, \mathrm{b}, \mathrm{c}$.

\section{Results}

The mean values and standard errors of means (SEM) of colostrum $\operatorname{IgG}$ concentrations are presented in Fig. 4. The concentrations of IgG obtained immediately after calving (time 0$)$ showing the significant difference $(\mathrm{P} \leq 0.05)$ between values of 
Mergedus, A.; Harih, G.; Hohler, A.; Janzekovic, I. \& Brus, M.: Comparison of Dif... colostimeter and refractometers. The highest values were obtained by digital refractometer $(93.4 \mathrm{~g} / \mathrm{L} \pm 6.9)$ and by optical refractometer $(92.9 \mathrm{~g} / \mathrm{L} \pm 6.2)$. There were no significant $(\mathrm{P}>0.05)$ difference. The concentrations obtained by colostrometer (namely $64.3 \pm 6.1 \mathrm{~g} / \mathrm{L})$ were significantly $(\mathrm{P} \leq 0.05)$ lower.

The similar results were found for the next consecutive samples at $3 \mathrm{~h}$ and $6 \mathrm{~h}$ after calving. After $3 \mathrm{~h}$, the highest concentrations were obtained by digital $(82.5 \mathrm{~g} / \mathrm{L}$ $\pm 5.9)$ and optical $(82.4 \mathrm{~g} / \mathrm{L} \pm 5.1)$ refractometer, respectively with no significant difference $(\mathrm{P}>0.05)$. Significant lower valu $(\mathrm{P} \leq 0.05)$ was obtained by colostrometer, $36.4 \pm 6.4 \mathrm{~g} / \mathrm{L}$. After $6 \mathrm{~h}$ postpartum, the results were similar. There were no significant $(\mathrm{P}>0.05)$ differences between optical $(76.7 \mathrm{~g} / \mathrm{L} \pm 6.6)$ and digital $(76,6 \mathrm{~g} / \mathrm{L} \pm 6.2)(\mathrm{P}$ $\leq 0.05)$ refractometer, but on the other hend the walues obtained by colostrometer were significantly $(\mathrm{P} \leq 0.05)$ lower $(30.8 \mathrm{~g} / \mathrm{L} \pm 6.1)$. In the following measurements, the colostrometer no longer showed results.

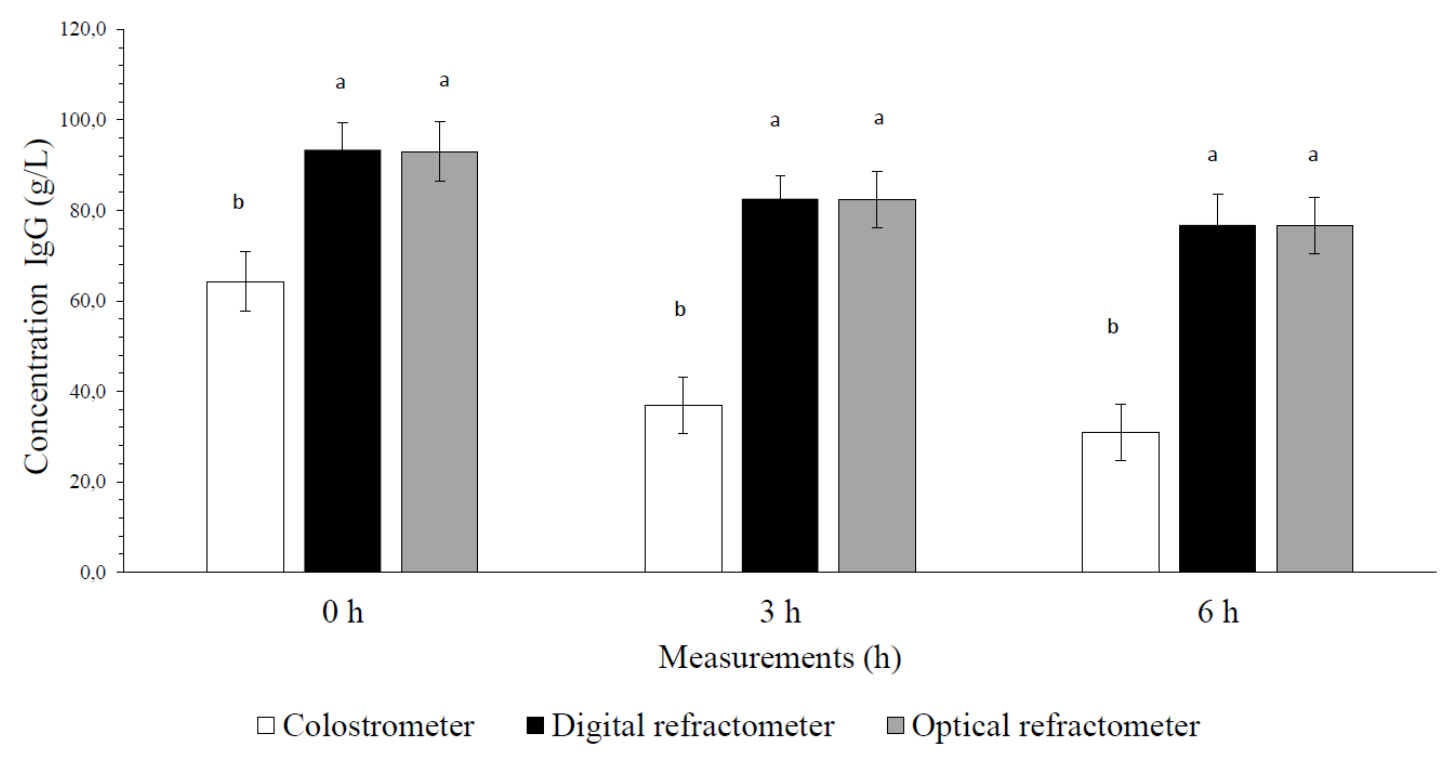

Fig. 4. The mean colostral IgG concentration measured with three measuring devices in three different times - immediately after and 3 and 6 hours after calving.

\section{Discussion}

The study's objectives were to analyse colostrum quality (immunoglobulin G, $\mathrm{IgG}$ ) at birth and after calving ( $3 \mathrm{~h}$ and $6 \mathrm{~h}$ ) with different evaluation (device) and to compare the obtained results. The colostral $\mathrm{IgG}$ concentration has traditionally been considered the hallmark for evaluating colostrum quality (Godden et al., 2009). Results of the analysis showed significant $(\mathrm{P} \leq 0.05)$ differences among the two refractometers and colostrometer. 
The digital and optical refractometers show very similar results, while the values obtained by the colostrometer are significantly $(\mathrm{P} \leq 0.05)$ lower concentrations of $\mathrm{IgG}$. The results are similar to the results published by Bartens et al. (2016). The study also indicates that both refractometers, when compared to the colostrometer, exhibit a higher level of sensitivity and specificity and have higher overall accuracy.

Considering the applied all tree devices, the colostrometer proved to be less accurate and also time-consuming. The Brix refractometers provided the most accurate values of evaluation of the colostrum quality in terms of accuracy and repeatability. The optical refractometer proved to be the most useful for on-farm evaluation as the results are comparable to the digital and also due to its affordability.

The goals for the future are directed in two main directions. First of all, it will be necessary to introduce an assessment of the quality of colostrum with a Brix meter in cattle breeding and to refine its use in different stable conditions. The second, more challenging goal is to link colostrum quality to the development of active immunity in calves. It will be necessary to establish fundamental non-invasive indicators to check passive immunity in calves after feeding with quality colostrum and correlation with subsequent active immunity.

\section{Acknowledgements}

The authors acknowledge support and are grateful for the hospitality of the Pucnik family farm.

\section{References}

Alley, M. L., Haines, D. M., \& Smith, G. W. (2012). Evaluation of Serum Immunoglobulin G Concentrations Using an Automated Turbidimetric Immunoassay in Dairy Calves. Journal of Dairy Science, 95(8), 4596-4599, ISSN: 0022-0302.

Bartier, A. L., Windeyer, M. C., \& Doepel, L. (2015). Evaluation of On-Farm Tools for Colostrum Quality Measurement. Journal of Dairy Science, 98(3), 1878-1884, ISSN: 0022-0302.

Bartens, M. C., Drillich, M., Rychli, K., Iwersen, M., Arnholdt, T., Meyer, L., \& KleinJöbstl, D. (2016). Assessment of Different Methods to Estimate Bovine Colostrum Quality on Farm. New Zealand Veterinary Journal, 64(5), 263-267, ISSN: 00480169. Butler, J. E. (1969). Bovine Immunoglobulins: A review. Journal of Dairy Science, 52(12), 1895-1909, ISSN: 0022-0302.

Conte, F., \& Scarantino, S. (2013). A Study on the Quality of Bovine Colostrum: Physical, Chemical and Safety Assessment. International Food Research Journal, 20(2), ISSN: 22317546.

Elsohaby, I., McClure, J. T., Cameron, M., Heider, L. C., \& Keefe, G. P. (2017). Rapid Assessment of Bovine Colostrum Quality: How Reliable are Transmission Infrared 
Mergedus, A.; Harih, G.; Hohler, A.; Janzekovic, I. \& Brus, M.: Comparison of Dif...

Spectroscopy and Digital and Optical Refractometers?. Journal of Dairy Science, 100(2), 1427-1435, ISSN: 0022-0302.

Godden, S. M., Haines, D. M., \& Hagman, D. (2009). Improving Passive Transfer of Immunoglobulins in Calves. I: Dose Effect of Feeding a Commercial Colostrum Replacer. Journal of Dairy Science, 92(4), 1750-1757, ISSN: 0022-0302.

McGrath, B. A., Fox, P. F., McSweeney, P. L., \& Kelly, A. L. (2016). Composition and Properties of Bovine Colostrum: A review. Dairy Science \& Technology, 96(2), 133-158, ISSN: 19585594.

Janzekovic, M., Rozman, C., Pazek, K., \& Pevec, P. (2014). Mathematical Model for Balancing Feed Rations in Dairy Cows, Chapter 12 in DAAAM International Scientific Book 2014, pp.153-162, B. Katalinic (Ed.), Published by DAAAM International, ISBN 978-3-901509-98-8, ISSN 1726-9687, Vienna, Austria.

McGee, M., \& Earley, B. (2019). Passive Immunity in Beef-suckler Calves. animal, 13(4), 810-825, ISSN: 1751-7311.

Morrill, K. M., Robertson, K. E., Spring, M. M., Robinson, A. L., \& Tyler, H. D. (2015). Validating a Refractometer to Evaluate Immunoglobulin G Concentration in Jersey Colostrum and the Effect of Multiple Freeze-thaw Cycles on Evaluating Colostrum Quality. Journal of Dairy Science, 98(1), 595-601, ISSN: 0022-0302.

Quigley, J. D., Lago, A., Chapman, C., Erickson, P., \& Polo, J. (2013). Evaluation of the Brix refractometer to estimate immunoglobulin $G$ concentration in bovine colostrum. Journal of Dairy Science, 96(2), 1148-1155, ISSN: 0022-0302.

Puppel, K., Gołębiewski, M., Grodkowski, G., Slósarz, J., Kunowska-Slósarz, M., Solarczyk, P. \& Przysucha, T. (2019). Composition and Factors Affecting Quality of Bovine Colostrum: A Review. Animals, 9(12), 1070, ISSN: 2076-2615.

Sacerdote, P., Mussano, F., Franchi, S., Panerai, A. E., Bussolati, G., Carossa, S. \& Bussolati, B. (2013). Biological Components in a Standardized Derivative of Bovine Colostrum. Journal of Dairy Science, 96(3), 1745-1754, ISSN: 0022-0302.

Yaylak, E., Güley, Z., \& Kulay, T. (2018). The Colostrum Quality and Composition of Simmental and Brown Swiss Heifers. Bioscience Journal, 34(2), ISSN: 19813163. 